\title{
A new species of Jasminum (Oleaceae) from Thailand
}

\author{
P. Chalermglin ${ }^{1}$, R. Kiew ${ }^{2}$
}

Key words

Critically Endangered

Jasminum

Oleaceae

Thailand
Abstract In revising the distribution and conservation status of Jasminum in Thailand, a new species, Jasminum bhumibolianum Chalermglin, was discovered in NE Thailand. It is described and illustrated and its conservation status is assessed as Critically Endangered.

Published on 2 September 2013

\section{INTRODUCTION}

The genus Jasminum in Thailand was revised by Kerr (1939) and Green (2000), the latter included 31 species of which two, J. decipiens P.S.Green and J. perissanthum P.S.Green, were described as new species (Green 1995). Since then J. rufohirtum Gagnep. was reported as a new record for Thailand (Srisanga et al. 2004).

Thailand Institute of Scientific and Technological Research (TISTR) is involved in a project to study the distribution and conservation of rare and endangered species as part of the Plant Genetic Conservation Project initiated by HRH Princess Maha Chakri Sirindhorne. Focus on the genus by the first author led to the discovery of this new species on a karst limestone hill in north-eastern Thailand. In comparing it with native species from neighbouring countries, such as Malaysia (Kiew 1994a, b), China (Chen et al. 1996) and Vietnam (Tran 2003), it proved to be a new species most similar to J. extensum Wall. ex G.Don and J. pierreanum Gagnep. in its unifoliolate, elliptic leaves with lateral veins where the basal vein is not more prominent than the others. However, the new species differs from both in its longer calyx lobes $3-4 \mathrm{~mm}$ long (vs $0.25-1 \mathrm{~mm}$ long), its shorter corolla tube 12-15 mm long (vs 15-22 mm long) and its 3-4 $\mathrm{mm}$ wide corolla lobes (vs $1-2 \mathrm{~mm}$ wide) and its larger, unlobed fruit (only one of the two lobes develops) and is ellipsoid, c. 11 by $9 \mathrm{~mm}$ (vs globose and 5-6 mm diam). Unlike the other two species, which are primarily species of evergreen forest, this new species is restricted to karst limestone. In addition, it is very different from other Thai jasmine species in its short, hard, triangular calyx lobes that are almost spine-like and in its 1-lobed fruit that when ripe detaches together with its pedicel and calyx.

\section{DESCRIPTION OF THE SPECIES}

\section{Jasminum bhumibolianum Chalermglin, sp. nov. — Fig. 1}

Similar to Jasminum extensum and J. pierreanum in its leaves, J. bhumibolianum is different from them in its calyx lobes $3-4 \mathrm{~mm}$ long (not $0.25-1 \mathrm{~mm}$ long), its short corolla 12-15 mm long (not 15-22 mm long) and its broader corolla lobes 3-4 $\mathrm{mm}$ wide (not 1-2 $\mathrm{mm}$ wide).

\footnotetext{
Thailand Institute of Scientific and Technological Research, 35 Mu 3, Khlong $\mathrm{Ha}$, Khlong Luang, Pathum Thani Province 12120, Thailand; corresponding author e-mail: piya@tistr.or.th.

${ }^{2}$ Forest Research Institute Malaysia, 52109 Kepong, Selangor, Malaysia.
}

Foliis Jasminum extenso et $\mathrm{J}$. pierreano similis, differt lobis calycis longis (3-4 mm nec $0.25-1 \mathrm{~mm}$ longis), tubis corollae brevibus (12-15 $\mathrm{mm}$ nec 15-22 mm longis), et lobis corollae latis (3-4 mm nec 1-2 mm latis). - Typus: Chalermglin 520705 (holo BKF; iso BK, K, KEP, L, QBG), north-eastern Thailand, Loei Province, 5 July 2009 (flowers).

Etymology. The species is dedicated to His Majesty King Bhumibol Adulyadej on his 84th anniversary in recognition of the great efforts he has made to conserve native plants in Thailand.

Woody climber, at base stem to $1 \mathrm{~cm}$ diam, branches thin, 1-2 m long, whole plant glabrous except for some short hairs on young shoot. Leaves unifoliolate; petiole $4-5 \mathrm{~mm}$ long, glabrous; lamina elliptic to broadly lanceolate and ultimately mucronate, $6-8(-9.5)$ by $3-3.5 \mathrm{~cm}$, chartaceous, base cuneate to rounded, margin not recurved, apex acuminate, lower surface without domatia; venation pinnate, lateral veins 3-4(-7) pairs, obscure, basal pair similar to the upper, vein pairs evenly spaced, ascending and joining $2-3(-3.5) \mathrm{mm}$ from margin, slightly impressed above and slightly prominent beneath, tertiary venation obscure. Inflorescence terminal on side shoots, slender, glabrous, cymose with 7-13(-19) flowers, sessile or sometimes with a peduncle $2-3 \mathrm{~mm}$ long; bracts foliose to $5-6$ $\mathrm{mm}$ long, glabrous; lateral branches to $15 \mathrm{~mm}$ long. Flowers with all parts glabrous, strongly fragrant; pedicels $0.5-2 \mathrm{~mm}$ long; bracteoles 2, filiform, $0.3-0.5 \mathrm{~mm}$ long. Calyx: tube 1-2 $\mathrm{mm}$ long; lobes 4-5, triangular, 3-4 mm long, hard and spinelike, glabrous. Corolla: tube $12-15(-17) \mathrm{mm}$ long, pale yellow below lobes; lobes $6-8$, white, lanceolate, $10-12.5$ by $3-4 \mathrm{~mm}$, margin smooth, apex acute to shortly acuminate. Stamens with filaments $0.5-1 \mathrm{~mm}$ long; anthers $3.5-4 \mathrm{~mm}$ long, dehiscing by longitudinal slits, connective appendage acute. Ovary barrelshaped, 0.5-1 mm long; style 4-5 mm long; stigma 1.5-2 mm long; ovules 2. Fruits 1-lobed, ellipsoid, c. $11 \mathrm{~mm}$ long, c. $9 \mathrm{~mm}$ wide, ripening purple-black.

Distribution - Endemic to Loei Province, north-eastern Thailand. Known only from the type locality.

Ecology - In mixed deciduous forest, growing in a gully on a karst limestone mountain. Altitude 715 m. Flowering JulySeptember; fruiting November-January.

Vernacular name - Mali Chaloem Narin (มะลิเฉลิมนรินทร์).

Conservation status - CR B1ab(iii). This new species, endemic to Thailand, is Critically Endangered (IUCN 2001), because it is known from a single locality where only two plants were discovered and the area is not legally protected.

Additional specimen examined. Chalermglin 531121 (BK, BKF, K, KEP, L, QBG), from type locality, 21 Nov. 2010 (fruits). 


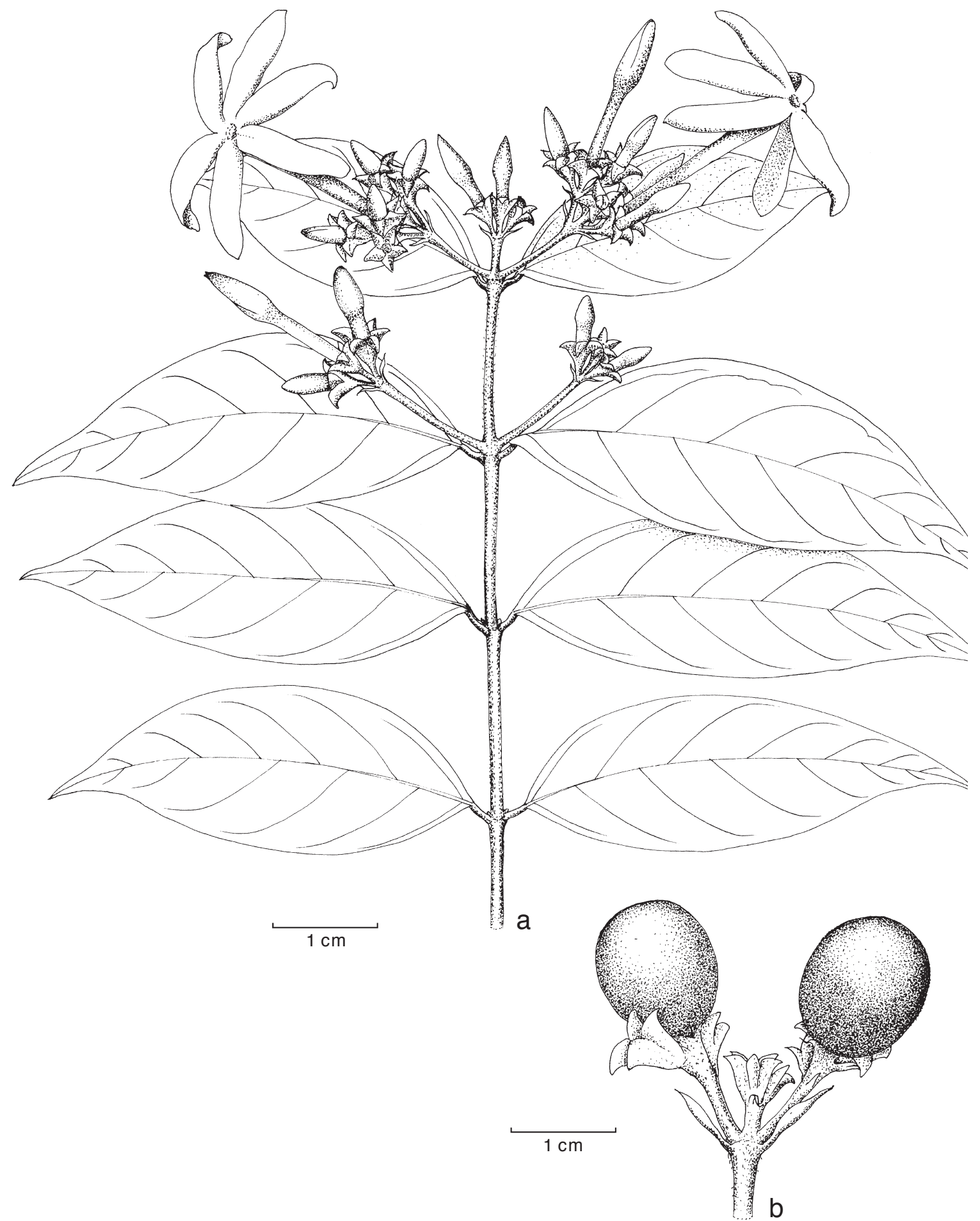

Fig. 1 Jasminum bhumibolianum Chalermglin. a. Habit; b. fruit (a: Chalermglin 520705, b: Chalermglin 531121).

Acknowledgements The first author is indebted to Dr. P. Suksathan of QBG for his valuable advice on distribution. We wish to thank the directors and curators of BK, BKF, BO, D, HAN, K, KEP, L, NY, P, PSU, QBG, SI and SING for granting permission to examine specimens in their care.

\section{REFERENCES}

Chen CM, Qing QL, Green PS. 1996. Oleaceae. In: Wu ZY, Raven PH (eds), Flora of China 15: 272-319. Beijing, Science Press \& St. Louis, Missouri Botanical Garden Press.

Green PS. 1995. New species and combinations, especially from Thailand: Studies in the genus Jasminum (Oleaceae): XIV. Kew Bulletin 50: 567-580. Green PS. 2000. Jasminum (Oleaceae). In: Santisuk T, Larsen K (eds), Flora of Thailand 7, 2: 306-340. The Forest Herbarium Royal Forest Department, Bangkok.
IUCN. 2001. IUCN Red List Categories and Criteria: Version 3.1. IUCN Species Survival Commission. IUCN, Gland, Switzerland and Cambridge, UK. Kerr AFG. 1939. Florae Siamensis Enumeratio 2: 395-407. Siam Society, Bangkok.

Kiew R. 1994a. Six new species of Jasminum (Oleaceae) from Malesia. Sandakania 4: 75-81.

Kiew R. 1994b. Checklist of Jasminum species (Oleaceae) in Malesia. Sandakania 5: 1-14.

Srisanga P, Trisonthi C, Green PS. 2004. Jasminum rufohirtum Gagnep. (Oleaceae), a new record for Thailand. Thai Forest Bulletin (Botany) 32: $146-148$.

Tran DL. 2003. Oleaceae. In: Nguyen Tien Ban et al. (eds), Checklist of flora of Vietnam 3: 1162-1172. Agriculture Publishing Hanoi. 